University of Nebraska - Lincoln

DigitalCommons@University of Nebraska - Lincoln

Faculty Publications from the Department of Electrical \& Computer Engineering, Department Electrical and Computer Engineering

2011

\title{
Self-Reconfigurable Multicell Batteries
}

Taesic Kim

University of Nebraska-Lincoln, taesickim@huskers.unl.edu

Wei Qiao

University of Nebraska-Lincoln, wqiao@engr.unl.edu

Liyan Qu

University of Nebraska-Lincoln, lqu2@unl.edu

Follow this and additional works at: https://digitalcommons.unl.edu/electricalengineeringfacpub

Part of the Electrical and Computer Engineering Commons

Kim, Taesic; Qiao, Wei; and Qu, Liyan, "Self-Reconfigurable Multicell Batteries" (2011). Faculty Publications from the Department of Electrical and Computer Engineering. 175.

https://digitalcommons.unl.edu/electricalengineeringfacpub/175

This Article is brought to you for free and open access by the Electrical \& Computer Engineering, Department of at DigitalCommons@University of Nebraska - Lincoln. It has been accepted for inclusion in Faculty Publications from the Department of Electrical and Computer Engineering by an authorized administrator of DigitalCommons@University of Nebraska - Lincoln. 


\section{Self-Reconfigurable Multicell Batteries}

\author{
Taesic Kim \\ Student Member, IEEE \\ Department of Electrical Engineering \\ University of Nebraska-Lincoln \\ Lincoln, NE 68588-0511 USA \\ taesickim@huskers.unl.edu
}

\author{
Wei Qiao \\ Member, IEEE \\ Department of Electrical Engineering \\ University of Nebraska-Lincoln \\ Lincoln, NE 68588-0511 USA \\ wqiao@engr.unl.edu
}

\author{
Liyan $\mathrm{Qu}$ \\ Member, IEEE \\ Department of Electrical Engineering \\ University of Nebraska-Lincoln \\ Lincoln, NE 68588-0511 USA \\ liyanqu@ieee.org
}

\begin{abstract}
The traditional multicell battery design usually employs a fixed configuration to connect multiple cells in series and parallel during operation in order to achieve the required voltage and current. However, this fixed configuration results in low reliability, low fault tolerance, and nonoptimal energy conversion efficiency. This paper proposes a novel selfreconfigurable, multicell battery design. The proposed multicell battery can automatically configure itself according to the dynamic load/storage demand and the condition of each cell. The proposed battery can self-heal from failure or abnormal operation of single or multiple cells, self-balance from cell state variations, and self-optimize to achieve the optimal energy conversion efficiency. These features are achieved by a new cell switching circuit and a high-performance battery management system (BMS) proposed in this paper. The proposed design is validated by simulation and experiment for a $6 \times 3$-cell polymer lithium-ion battery. The proposed design is universal and can be applied to any type and size of battery cells.
\end{abstract}

\section{INTRODUCTION}

Rechargeable multicell batteries have been used in various industrial, commercial and residential systems and devices. The latest battery cell technologies, such as LiFePO4 (Lithium Iron Phosphate) and nLTO (nano Lithium Titanate Oxide), have largely solved most critical concerns in terms of safety, cycle and calendar life, energy density, gravimetric density, specific density, charge/discharge capability, and fast charge capability. However, several design deficiencies in current multicell battery systems have impeded them from being used for large-scale energy storage, which are 1) adopting a fixed configuration for cell connections, resulting in a low reliability and low fault-tolerance capability from abnormal operating conditions, such as high temperature, overcharge, over-discharge, and over-current [1]; 2) lacking an effective method to utilize cell state variations, resulting in a nonoptimal energy conversion efficiency; and 3) lacking a capability for flexible dynamic power management, resulting in a nonoptimal system performance.

A commonly used method to solve the problem of faulty or abnormal cells in a fixed-configuration design is safety circuits. Safety circuits protect cells from high temperature,

This work was supported by the U.S. National Science Foundation under CAREER Award ECCS-0954938. overcharge, over-discharge, and over-current by monitoring the temperature, voltage, and current of each cell. However, lacking an effectively reconfigurable topology, the safety circuits will cut off the whole battery system when any single cell is operated in these abnormal conditions. Cell state variations are commonly present in multicell batteries [3]. In this case, the fixed-configuration design can only utilize a part of the total battery capacity, which reduces the operating time and lifespan of the battery system. To overcome this deficiency, cell balancing circuits are used. However, most existing balancing circuits use dissipative resistors, resulting in energy loss [4]. The latest products of cell balancing integrated circuits (ICs) [5] use electronic converters to transfer charge from cell to cell during operation. However, this solution increases the cost and volume of the battery system and it might only available for batteries with mutiple cells connected in series. Recently, several reconfigurable multicell battery topologies have been proposed for portable electronic devices [6]-[8]. However, these topologies are too complex and unrealistic for the battery systems with large numbers of cells. In [9], the authors proposed a reconfigurable multicell battery design where multiple cells are only connected in series to achieve the required voltage level.

This paper extends the work of [9] by proposing a novel self-reconfigurable multicell battery design, where multiple cells can be dynamically configured in series and in parallel during operation to achieve the required voltage and current, respectively. A new cell switching circuit is proposed where each cell in the battery only uses one switch to fully control its charge, discharge, and cutoff independently. A new gate drive circuit is designed for controlling on/off of each switch in the cell switching circuit. A new battery management system (BMS) is proposed to perform the functions of sensing, modelbased performance tracking, scheduling, control, protection, etc., for the battery system. Consequently, the proposed battery system can dynamically configure itself during operation according to the load/storage demand and the condition of each cell to achieve self-healing from failures of single or multiple cells, self-balancing from cell state variations, and self-optimizing for optimal energy conversion efficiency. Compared to existing reconfigurable battery topologies [6]-[8], the number of switches in the proposed topology is 
significantly reduced. This reduces the cost, complexity, and control effort of the battery system and facilitates the reconfiguration process.

\section{Proposed Self-Reconfigurable Multicell Battery DESIGN}

The proposed self-reconfigurable multicell battery consists of three parts: (1) a cell pack, (2) a cell switching circuit, and (3) a BMS, as shown in Fig. 1.

\section{A. The Cell Pack}

The nominal voltages and currents of most single battery cells are limited to several volts and tens of amperes, e.g., 3.7 $\mathrm{V}$ and $0.86 \mathrm{~A}$ for the polymer lithium-ion cells used in this paper, which are much lower than the voltages and currents required in many applications. In the proposed design, the cell pack consists of $m \times n$ cells, which are dynamically configured by the cell switching circuit during operation to meet voltage and current requirements.

\section{B. The Cell Switching Circuit}

Fig. 2 shows the proposed cell switching circuit topology for an $m \times n$-cell battery pack, where $n$ cells are connected in parallel to form a cell bank to provide a higher current; and $\mathrm{m}$ banks are connected in series to step up the voltage at the terminals of the battery. Only $\mathrm{m} \times(\mathrm{n}+1)$ controllable switches are needed to form the cell switching circuit. Each cell only uses one switch, e.g., the switch $S_{i j}$ for Cell $C_{i j}(i=1, \cdots, m$ and $j=1, \cdots, n)$, which turn on/off alternatively to connect/cut off the cell from the battery, respectively. Moreover, if switch $\mathrm{S}_{\mathrm{ij}}$ is on, it will be able to conduct the current of Cell $\mathrm{C}_{\mathrm{ij}}$ in two directions to charge/discharge the cell. Additional $\mathrm{m}$ switches $\mathrm{S}_{1}, \cdots, \mathrm{S}_{\mathrm{m}}$ are used where $S_{i}(i=1, \cdots, m)$ is off if any of the $n$ switches $\left(\mathrm{S}_{\mathrm{i} 1}, \cdots, \mathrm{S}_{\mathrm{in}}\right)$ in bank $\mathrm{i}$ is on. However, if all of the $\mathrm{n}$ switches in bank $\mathrm{i}(\mathrm{i}=1, \cdots, \mathrm{m})$ are off, then $\mathrm{S}_{\mathrm{i}}$ should be turned on. Turning on $S_{i}$ ensures that the cells in lower rows $\left(S_{(i+1) 1}, \cdots\right.$, $\mathrm{S}_{(\mathrm{i}+1) \mathrm{n}}, \cdots, \mathrm{S}_{\mathrm{ml}}, \cdots, \mathrm{S}_{\mathrm{mn}}$ ) can be connected to supply (discharge) or store (charge) energy through the terminals of the battery. The proposed cell switching circuit ensures that each cell in

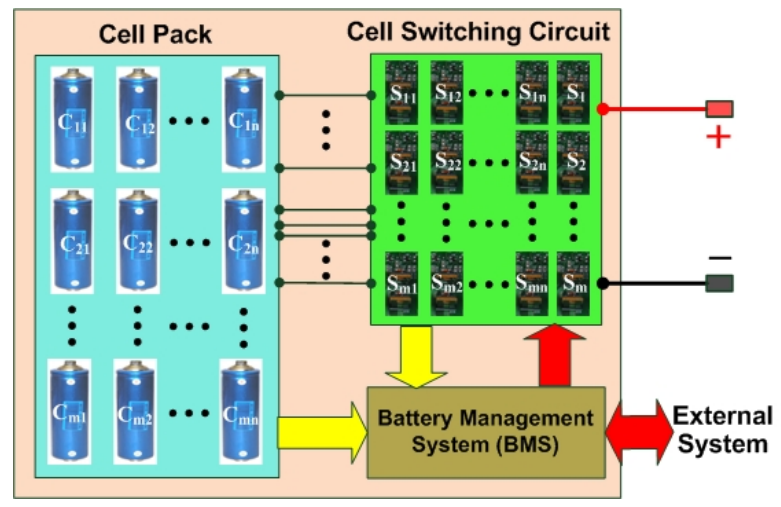

Fig. 1. The proposed self-reconfigurable, multicell battery design.

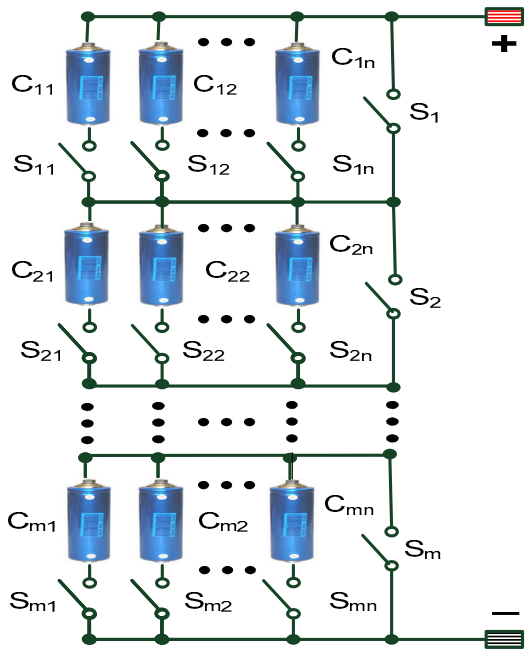

Fig. 2. The proposed cell switching circuit topology.

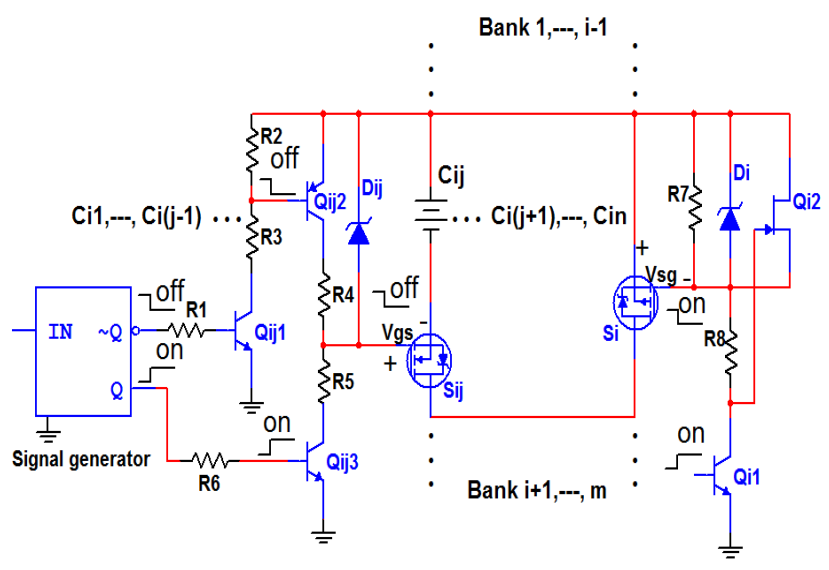

Fig. 3. Switch implementation for Cell $\mathrm{C}_{\mathrm{ij}}$ using an n-channel power MOSFET and for Bank i using a p-channel power MOSFET with the gate drive circuit.

the battery pack can be controlled independently in three modes, i.e., off, on/charge, and on/discharge.

Low-cost, high-efficiency power MOSFETs are used for implementation of the switches in the cell switching circuit.

These power MOSFETs can conduct bidirectional currents and have a negligible conduction loss because of their negligible "on" resistance (see Appendix). In this application, switching losses are not a concern because it typically takes a long time, e.g., 10 minutes or longer, for a switch to change its state.

Fig. 3 illustrates a switch implementation for Cell $\mathrm{C}_{\mathrm{ij}}(\mathrm{i}=$ $1, \cdots, m$ and $j=1, \cdots, n$ ) using an $n$-channel power MOSFET $\left(\mathrm{S}_{\mathrm{ij}}\right)$ and for Bank i using a p-channel power MOSFET $\left(\mathrm{S}_{\mathrm{i}}\right)$ with a gate drive circuit. The gate drive circuit is implemented by using low-cost, small-signal BJTs $\left(\mathrm{Q}_{\mathrm{ij} 1}, \mathrm{Q}_{\mathrm{ij}}\right.$, $\mathrm{Q}_{\mathrm{ij} 3}$, and $\left.\mathrm{Q}_{\mathrm{i} 1}\right)$ and a JFET $\left(\mathrm{Q}_{\mathrm{i} 2}\right)$. The gate drive circuit only uses the voltage of Cell $\mathrm{C}_{\mathrm{ij}}$ to turn on the power MOSFET $\mathrm{S}_{\mathrm{ij}}$; no additional voltage source is required. The small-signal 


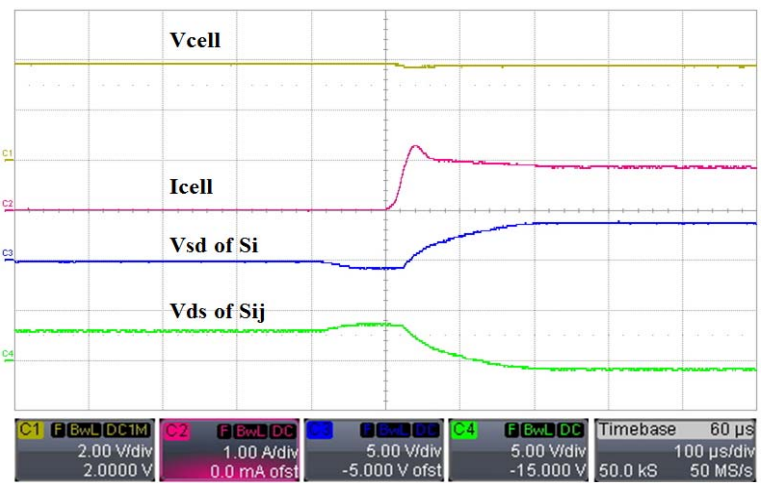

(a)

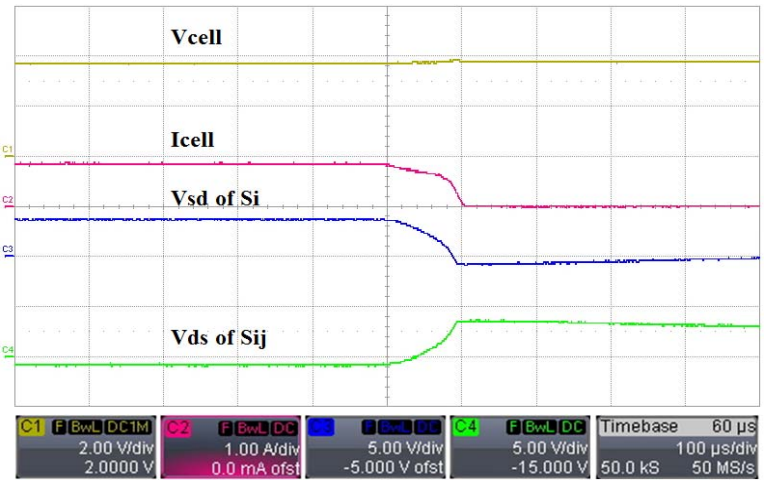

(b)

Fig. 4. Transient waveforms of the switching implementation for Cell $\mathrm{k}$ in Fig. 3 operating 1C (0.86 A) load current: (a) $\mathrm{S}_{\mathrm{ij}}$ on and $\mathrm{S}_{\mathrm{i}}$ off; (b) $\mathrm{S}_{\mathrm{ij}}$ off and $\mathrm{S}_{\mathrm{i}}$ on.

BJTs can be replaced by small-signal MOSFETs for the gate drive circuit operating under $100 \mathrm{~V}$. When $\mathrm{Q}_{\mathrm{ij} 1}$ turns on, it drives $\mathrm{Q}_{\mathrm{ij} 2}$ on, which turns on $\mathrm{S}_{\mathrm{ij}}$. Turning off $\mathrm{S}_{\mathrm{ij}}$ is accomplished when $\mathrm{Q}_{\mathrm{ij} 3}$ turns on. When $\mathrm{Q}_{\mathrm{i} 1}$ turns on, it provides a gate signal to turn on the power MOSFET $\mathrm{S}_{\mathrm{i}}$. Turning off $\mathrm{S}_{\mathrm{i}}$ is performed by $\mathrm{Q}_{\mathrm{i} 2}$ and $\mathrm{R} 7$. The value of $\mathrm{R} 7$ should be large enough to ensure that the energy consumption of the gate drive circuit is negligible, which however results in slow turn-off of $\mathrm{S}_{\mathrm{i}}$ if a BJT is used for $\mathrm{Q}_{\mathrm{i} 2}$. The use of a JFET for $\mathrm{Q}_{\mathrm{i} 2}$ makes the turn-off of $\mathrm{S}_{\mathrm{i}}$ fast. In this switching implementation, an n-channel MOSFET with a low threshold $V_{g s}$ (e.g., 1.5 2 V) should be used for $\mathrm{S}_{\mathrm{ij}}$. The Zener diodes, $\mathrm{D}_{\mathrm{ij}}$ and $\mathrm{D}_{\mathrm{i}}$, are used to limit the voltage between the source and the gate terminals of $\mathrm{S}_{\mathrm{ij}}$ and $\mathrm{S}_{\mathrm{i}}$, respectively. Resistance values and small-signal components are appropriately chosen to ensure that the energy consumption of the gate drive circuit is negligible compared to the energy flow in the cell and no short circuit occurs during transient switching periods.

Fig. 4 illustrates the transient waveforms of Cell $\mathrm{C}_{\mathrm{ij}}$ operating with a $1 \mathrm{C}(0.86 \mathrm{~A})$ load current using the switching implementation in Fig. 3. During the transient switching periods, the transitions of the cell voltage and current are smooth and there is no short circuit between $S_{i j}$ and $S_{i}$.

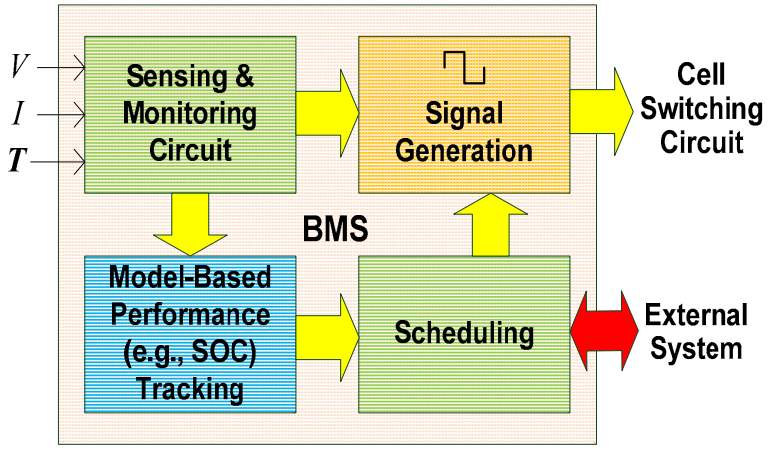

Fig.5. Schematic diagram of the battery management system (BMS).

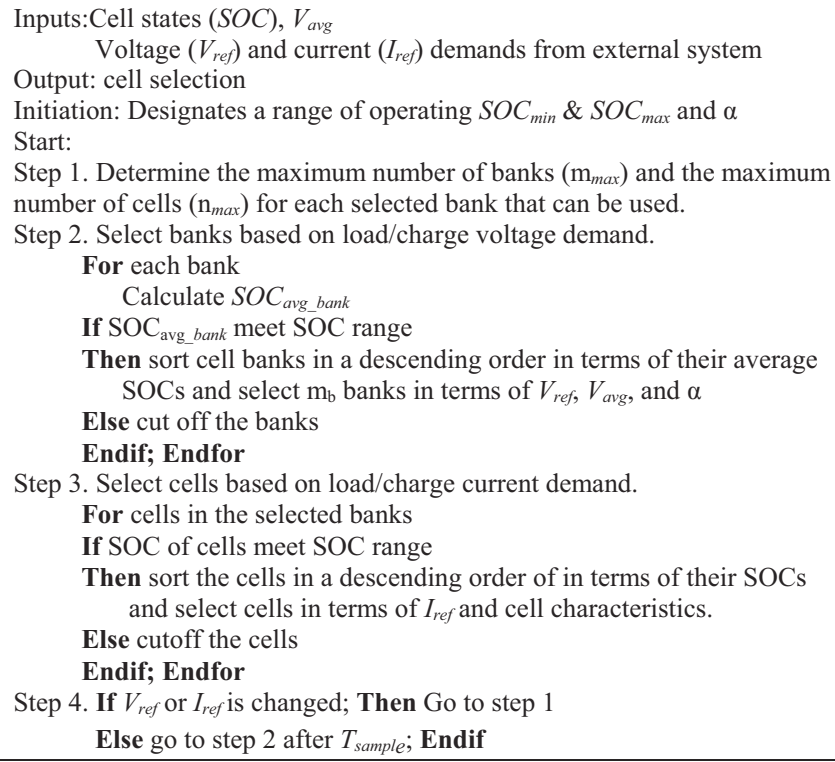

Step 1. Determine the maximum number of banks $\left(\mathrm{m}_{\max }\right)$ and the maximum number of cells $\left(\mathrm{n}_{\max }\right)$ for each selected bank that can be used.

Step 2. Select banks based on load/charge voltage demand. For each bank

Fig. 6. The proposed optimal scheduling algorithm.

Therefore, the switching circuit in Fig. 3 is well design and will not cause any stress on Cell $\mathrm{C}_{\mathrm{ij}}$ during transient switching periods.

\section{The Battery Management System (BMS)}

The BMS, as shown in Fig. 5, performs functions of sensing, condition monitoring, cell modeling, scheduling, protection, gate signal generation, and interfacing with external systems for the battery. The sensing and monitoring circuit monitors the voltage, current, and temperature, for each cell to protect it from overcharge/over-discharge, overcurrent, and over-temperature. If these abnormal conditions exist in cells, they are cut off immediately. The state of charge (SOC) of each cell is estimated by a model-based method using the cell voltage, current, and temperature [10].

The optimal scheduling module determines the best configuration of cells based on the dynamic load/storage 
demand and the condition of each cell to maximize the energy conversion efficiency of the battery. An optimal scheduling algorithm is proposed, as shown in Fig. 6, where $V_{\text {avg }}$ is the average voltage of the banks of the battery. The optimal scheduling algorithm does not consider the cells in abnormal conditions. Before starting the system, the range of the operating SOC and the bound of voltage margin $\alpha$ will be set, where $\alpha$ is the estimated voltage drop in the discharge mode or the estimated voltage rise in the charge mode. The operating SOC depends on applications and cell specifications. The optimal scheduling algorithm consists of four steps. Step 1 determines the maximum numbers of banks and cells that can be used to reach the required voltage and current levels ( $V_{\text {ref }}$ and $\left.I_{r e f}\right)$, respectively, where $\mathrm{m}_{\max }$ is the number of healthy banks; $\mathrm{n}_{\max }$ is the number of healthy cells in the selected banks. The selection of cells in a bank is based on $I_{\text {ref }}$ and the nonlinear capacity characteristics of the cells, such as the rate capacity effect and recovery effect [11]. For instance, if $I_{\text {ref }}$ is smaller than $1 \mathrm{C}$ of any individual cell, the available cells in a bank will be connected one by one in sequence to use the recovery effect. As the load current becomes heavier, the number of cells connected in parallel simultaneously in a bank should be increased for best performance since the rate capacity effect would be more significant than the recovery effect in this case. In Step 4, once the banks and cells in the banks are selected, the reconfiguration of the battery cells can be done with a specified reconfiguration time interval $T_{\text {sample }}$, e.g., $T_{\text {sample }}=10$ minutes if the voltage $\left(V_{\text {ref }}\right)$ and current $\left(I_{r e f}\right)$ demands do not change. The value of $T_{\text {sample }}$ Will reduces with the increase of the discharge current. By reallocates the healthy banks and the healthy cells in each selected bank, the proposed design is able to utilize recovery effect to improve energy conversion efficiency of the battery. According to the output of the scheduling module, the signal generation module generates appropriate control signals to control each power switch through its gate drive circuit.

\section{MODELING OF BATTERY CELLS}

An accurate battery cell model is needed in order to validate the proposed multicell design by simulation studies. Moreover, monitoring, control, protection, and optimization of battery systems also need an accurate battery cell model for SOC tracking, etc. In this paper, a hybrid battery model is

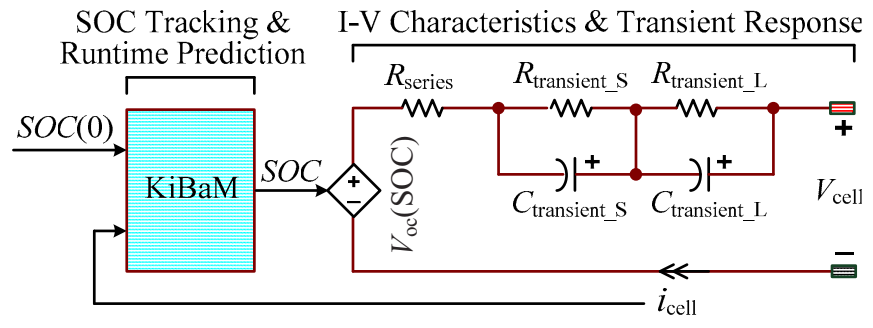

Fig. 7. The proposed hybrid battery model.

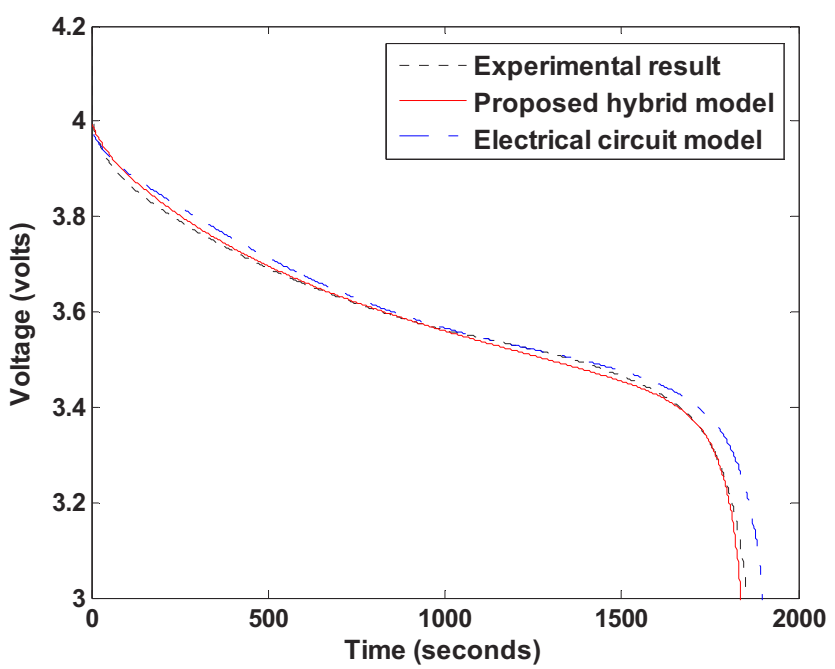

Fig. 8. Comparison of simulation and experimental results for 1.86C (1.6A) constant discharge of a single cell.

used. The proposed hybrid model enhances the electrical circuit model [12] by replacing its left-hand-side RC circuit with a module based on the Kinetic Battery Model (KiBaM) [13] to capture the nonlinear capacity variations of the battery, such as the recovery effect and rated capacity effect, as shown in Fig. 7. Therefore, the proposed model is capable of capturing comprehensive battery performance more accurately than the electrical circuit model by coupling the dynamic electrical circuit characteristics with nonlinear capacity effects of the battery. In addition, the proposed battery model needs less computational cost than the enhanced circuit-based model in [14], thereby is feasible for real-time applications. The module on the left is used to represent SOC tracking and runtime prediction for the battery cell. A voltage-controlled voltage source is used to bridge SOC to battery open-circuit voltage. The open-circuit voltage, internal series resistance $\left(R_{\text {series }}\right)$ and RC networks are used to model electrical circuit characteristics the transient voltage response of the battery cell.

Fig. 8 compares experimental results with both the electrical circuit model and the hybrid model at a constant discharge current rate of $1.86 \mathrm{C}$ (1.6A) for a single cell. Unlike the electrical circuit model, the hybrid model can still capture dynamic circuit characteristics and provide accurate runtime prediction for the battery cell at high discharge current.

\section{SIMULATION RESULTS}

A $6 \times 3$-cell battery module is built by using the proposed design and is simulated in MATLAB/Simulink. Each cell is a 3.7-V, 860-mAh polymer lithium-ion cell (see Appendix), which is represented by the hybrid battery model in Section III. Assuming all the cells in the same bank have the same 


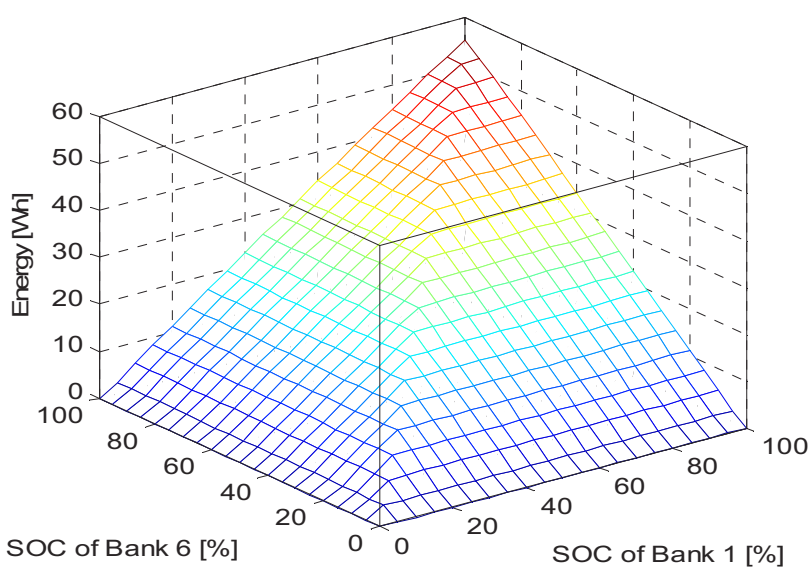

(a)

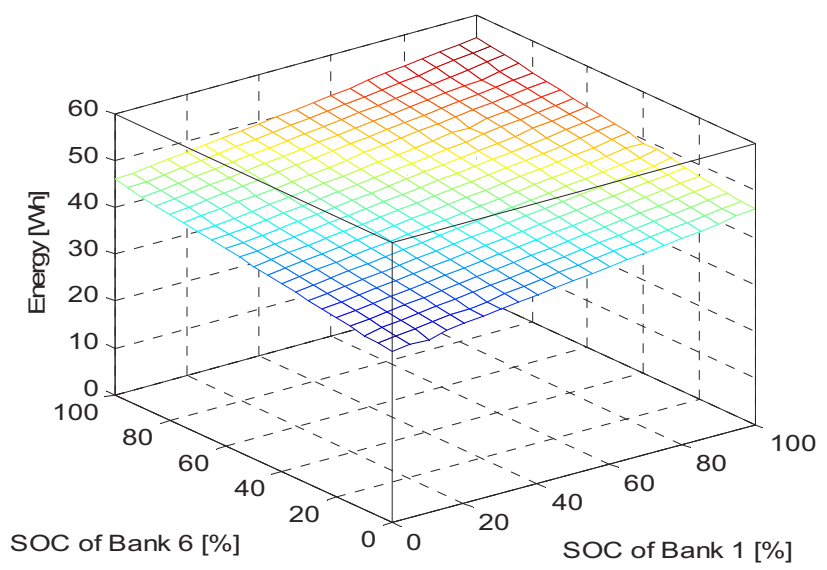

(b)

Fig. 9. Total energy in Wh that can be supplied by (a) the fixed-configuration and (b) the proposed self-reconfigurable, $6 \times 3$-cell batteries

SOC and the initial SOCs of Banks 2-5 are all at 100\%, Fig. 9(a) and (b) compare the total energy in Wh that can be supplied by the fixed-configuration and the proposed selfreconfigurable batteries for different SOCs of Banks 1 and 6. These results clearly show that the proposed design significantly improves the energy usage of the multicell battery. For example, when the SOC of Bank 1 or 6 or both becomes zero, the whole battery with the fixed configuration has to be cut off and cannot supply any energy to the load although the usable capacity of the battery is still significant. On the other hand, the proposed reconfigurable battery can supply energy from other banks even the SOC of one or both of Banks 1 and 6 becomes zero. For example, in the worst case when the SOCs of Banks 1 and 6 are both zero, the reconfigurable battery can still supply totally $36.88 \mathrm{Wh}$ energy from Banks 2-5, which is $66.7 \%$ of the maximum energy capacity of the battery. This shows the self-healing feature of the proposed design.

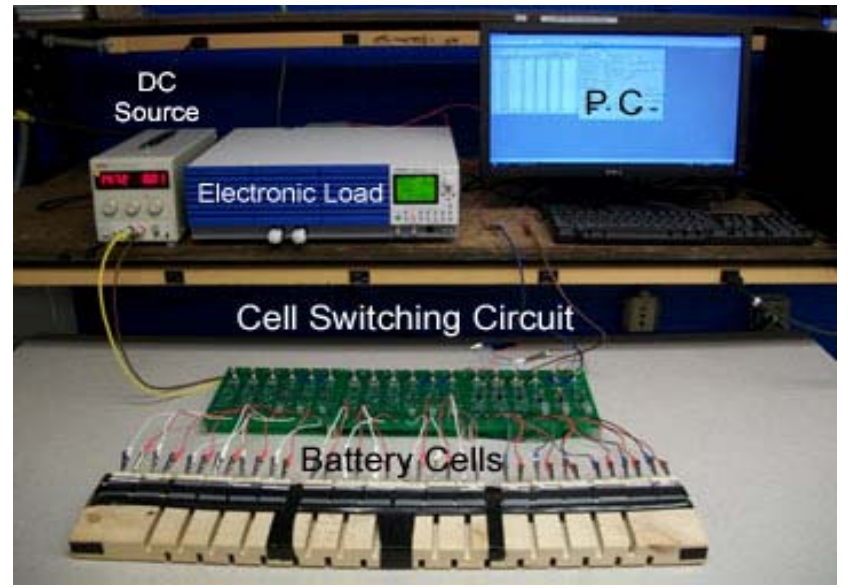

Fig. 10. The experimental setup

\section{EXPERIMENTAL RESULTS}

The self-reconfigurable multicell battery used in simulation studies is constructed in hardware to further validate the proposed design. Fig. 10 shows the experimental setup. High-efficiency power MOSFETs are used to form the cell switching circuit on a PCB. The dSPACE system consists of a DS1005 PPC, a 16 bit high resolution A/D broad DS2002, a digital waveform output broad DS5101, a multifunction digital I/O board DS 4002 on which the BMS is implemented with the aid from the tools of RTW and RTI of dSPACE. The sensing, control and protection functions are also implemented on the PCB. The cells are charged by a variable DC source and discharged through a programmable DC electronic load. Table 1 compares the simulation results of the proposed self-reconfigurable battery design and the fixed-configuration design as well as the simulation and experimental results for the proposed self-reconfigurable battery design for three scenarios. Scenario 1 and 2 are used to validate self-healing feature of the proposed design. Selfoptimizing for optimal energy conversion efficiency is validated by scenario 3 . In all scenarios, the discharge current of the battery is $2.58 \mathrm{~A}$ (i.e., 1C). For all scenarios, the experimental results agree with the simulation results.

In Scenarios 1 and 2, the 18 cells are discharged simultaneously using the constant current (C.C.) mode. Since the initial SOCs of the cell banks are different, the cell banks are fully discharged sequentially. In the fixed-configuration design, once a cell bank is fully discharged, the whole battery has to be cut off and cannot supply any energy to the load although the usable capacity of the battery is still significant. In the proposed design, once a cell bank is fully discharged, it will be disconnected from the battery pack by the cell switching circuit but the remaining cell banks still provide energy to the load. Compared to the fixed-configuration design, the proposed self-reconfigurable design can supply $16 \mathrm{Wh}$ and $24.73 \mathrm{Wh}$ more energy, which are $28.9 \%$ and 


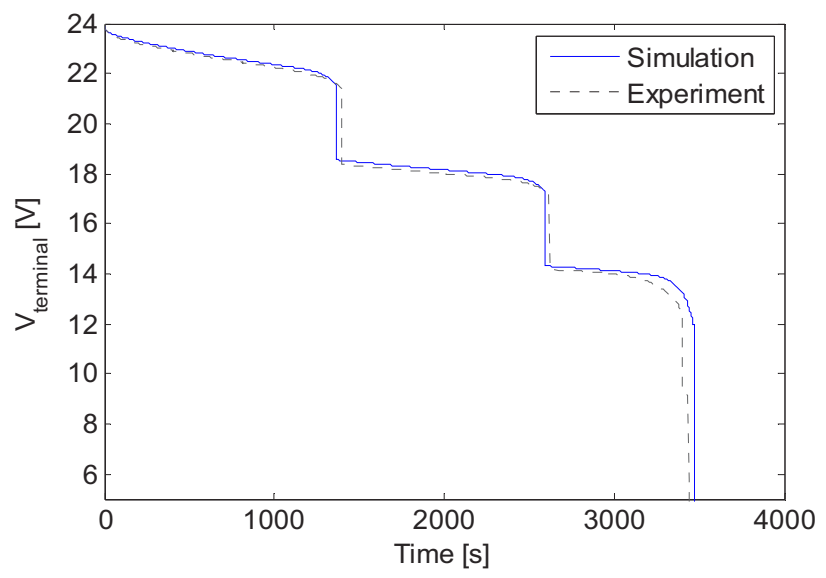

Fig.11. Comparison of the terminal voltage responses of the selfreconfigurable battery obtained from simulation and experiment for Scenario 2 .

$44.7 \%$ of the maximum capacity of the battery, in Scenarios 1 and 2 , respectively.

Fig. 11 compares the terminal voltage response of the self-reconfigurable battery obtained from simulation and experiment for Scenario 2, which shows that not only the steady-state but also the dynamic responses of the battery obtained from simulations agree with those from experiments. Therefore, the comparison in Fig. 6 is effective to validate the superiority of the proposed self-reconfigurable battery design over the traditional fixed-configuration design.

In Scenario 3, the six banks of the self-reconfigurable battery are divided into two groups and each group has three banks, which is $\mathrm{m}=3$ and $\mathrm{n}=\mathrm{n}_{\max }$ in optimal scheduling of BMS. The two groups of cell banks are discharged alternately, i.e., pulse discharge (P.C.), with a time interval of $300 \mathrm{~s}$ until all the cells are fully discharged. Compared to the fixed-configuration battery that uses C.C. discharge, more energy $(\sim 1 \mathrm{Wh})$ is supplied by the self-reconfigurable battery when using the P.C. discharge. The P.C. discharge method utilizes the recovery effect to improve the energy conversion efficiency of the battery cells, which however cannot be achieved by the traditional fixed-configuration battery design.

In the rated case where the cell is operated at the rated voltage of $3.7 \mathrm{~V}$ and maximum current of $0.86 \mathrm{~A}$, a cell's power is $3182 \mathrm{~mW}$. The conduction loss of MOSFETs and current sensors is approximately $2.4 \mathrm{~mW}$ and the total power loss of the gate drive circuit, sensing and control circuits is approximately $1040 \mathrm{~mW}$, which means the power loss is about $58 \mathrm{~mW}$ per cell. Therefore, the efficiency of the battery system is higher than $98 \%$ and can be further improved by using higher-efficiency devices.

\section{CONCLUSION AND FUTURE WORK}

This paper has presented a novel self-reconfigurable multicell battery design. The proposed multicell battery can automatically configure itself according to the dynamic load/storage demand and the condition of each cell, self-heal from failures and abnormal operating conditions of single or multiple cells, self-balance from cell state variations, and self-optimize to achieve the optimal energy conversion efficiency. These features are achieved by a cell switching circuit and a high-performance BMS proposed in this paper. The proposed design can maximally utilize the battery's capacity and is tolerant to failures of single or multiple cells, thereby maximizing the lifespan and enhancing the reliability of the battery. Simulation and experimental results have shown a remarkably improved energy usage of multicell batteries using the proposed design. The proposed design is universal and can be applied to any type and size of battery cells. Based on the proposed design, the research on self-balancing function and external power electronic circuit, e.g., the $\mathrm{dc} / \mathrm{dc}$ converter for battery charge/discharge, is under investigation and will be reported in future work.

\section{APPENDIX}

The parameters of the components used in the simulation and experimental studies are listed as follows.

1) Battery cell: pl-383562 2C (polymer lithium-ion); nominal voltage: $3.7 \mathrm{~V}$; nominal capacity: $860 \mathrm{mAh}$; discharge cutoff voltage $\left(V_{\text {cutoff }}\right): 3 \mathrm{~V}$; charge cutoff voltage $\left(V_{\text {over }}\right)$ : $4.2 \mathrm{~V}$; maximum discharge current: 2C (1.72 A).

2) Power MOSFET: n-Channel MOSFET: AON6400L $\left(\mathrm{S}_{\mathrm{ij}}\right), V_{D S S}=30 \mathrm{~V}, R_{D S(\text { on })}=1.8 \mathrm{~m} \Omega, V_{\text {th }}=1.7 \mathrm{~V}$; p-Channel MOSFET: IPD90P03P4L-04 $\left(\mathrm{S}_{\mathrm{i}}\right) V_{D S S}=-30 \mathrm{~V}, R_{D S(\text { on })}=$ $4.1 \mathrm{~m} \Omega, V_{t h}=-1.5 \mathrm{~V}$.

Table I: Comparison of simulation and experimental results

\begin{tabular}{|c|c|c|c|c|c|c|c|c|c|c|}
\hline \multirow{3}{*}{ Scenario } & \multirow{3}{*}{ Discharge method } & \multicolumn{6}{|c|}{ Initial conditions of cell banks expressed by SOC [\%] } & \multicolumn{3}{|c|}{ Energy $[\mathrm{Wh}]$} \\
\hline & & \multirow{2}{*}{ Bank 1} & \multirow{2}{*}{ Bank 2} & \multirow{2}{*}{ Bank 3} & \multirow{2}{*}{ Bank 4} & \multirow{2}{*}{ Bank 5} & \multirow{2}{*}{ Bank 6} & \multicolumn{2}{|c|}{ Self-reconfigurable design } & \multirow{2}{*}{$\begin{array}{l}\text { Fixed-configuration } \\
\text { design (Simulation) }\end{array}$} \\
\hline & & & & & & & & Simulation & Experiment & \\
\hline 1 & C.C. $=2.58 \mathrm{~A}$ & 80 & 100 & 100 & 100 & 100 & 60 & 49.5 & 49.0 & 33.5 \\
\hline 2 & C.C. $=2.58 \mathrm{~A}$ & 75 & 100 & 100 & 100 & 100 & 40 & 47.1 & 46.87 & 22.37 \\
\hline 3 & $\begin{array}{l}\text { C.C. }=2.58 \text { A; P.C. }=2.58 \\
\text { A }(300 \text { s on, } 300 \text { s off })\end{array}$ & 100 & 100 & 100 & 100 & 100 & 100 & 56.32 (P.C.) & 56.0 (P.C.) & 55.3 (C.C.) \\
\hline
\end{tabular}


3) Small-signal transistor: MMBT $2222\left(\mathrm{Q}_{\mathrm{ij} 1}, \mathrm{Q}_{\mathrm{ij} 3}\right.$ and $\left.\mathrm{Q}_{\mathrm{i} 1}\right)$, MMBT $2907\left(\mathrm{Q}_{\mathrm{ij} 2}\right)$.

4) Small-signal JFET: MMBFJ201 $\left(\mathrm{Q}_{\mathrm{i} 2}\right)$.

5) Monitoring circuit: voltage sensor: LT1991; current sensor: ACS706ELC-05C, $R_{D S(o n)}=1.5 \mathrm{~m} \Omega$.

\section{REFERENCES}

[1] D. Linden and T. B. Reddy, Handbook of Batteries, 3rd ed., McGrawHill, 2001.

[2] Electronic Publication: MAX 11080 Datasheet, "12-Channel, High voltage Battery-Pack Fault Monitor", MAXIM.

[3] O. Erdinc, B. Vural, and M. Uzunoglu, "A dynamic lithium-ion battery model considering the effects of temperature and capacity fading," in Proc. 2009 International Conference on Clean Electrical Power, June 9-11, 2009, pp. 383-386.

[4] J. Cao, N. Schofiled, and. A. Emadi, "Battery balancing methods: A comprehensive review", in Proc. IEEE Vehicle Power and Propulsion Conference, Sept. 3-5, 2008, Harbin, China.

[5] Electronic Publication: BQ 102 Datasheet, "Power LAN Dual-Cell LiIon Battery Monitor with Power Pump Cell Balancing", Texas Instrument.

[6] S. Ci, J. Zhang, H. Sharif, and M. Alahmad "A novel design of adaptive reconfigurable multicell battery for power-aware embedded networked sensing system," in Proc. 2007 IEEE Global Telecommunication Conference, Nov. 26-30, 2007, pp. 1043-1047.

[7] S. K. Mandal, P. S. Bhojwani, S. P. Mohanty, and R. N. Mahapata, "IntellBatt: Towards smarter battery design," in Proc. 45th Annual ACM/IEEE Design Automation Conference, June 8-13, 2008, pp. 872877.

[8] H. Visairo and P. Kumar, "A reconfigurable battery pack for improving power conversion efficiency in portable devices", in Proc. 7th International Caribbean Conference on Devices, Circuits and Systems, Apr. 28-30, 2008, Mexico.

[9] T. Kim, W. Qiao, and L. Qu, "Series-connected reconfigurable multicell battery: A novel design towards smart batteries," in Proc. IEEE Energy Conversion Congress and Exposition 2010, Atlanta, GA, USA, Sept. 12-16, 2010, pp. 4257-4263.

[10] F. Codecà, S. Savaresi and V. Manzoni, "The mix estimation algorithm for battery state-of-charge estimator analysis of the sensitivity to measurement errors," in Proc. Joint 48th IEEE Conference on Decision and Control and 28th Chinese Control Conference Shanghai, P.R. China, Dec. 16-18, 2009.

[11] V. Rao, G. Singhal, A. Kumar, and N. Navet, "Battery modeling for embedded systems," in Proc. $18^{\text {th }}$ International Conference on VLSI Design, 2005, pp 105-110.

[12] M. Chen and G. A. Rincon-Mora, "Accurate electrical battery model capable of predicting runtime and I-V performance," IEEE Trans. Energy Conversion, vol. 21, no.2, pp. 504-511, June 2006.

[13] J. Manwell and J. Mcgowan, "Extension of the kinetic battery model for wind/hybrid power system," in Proc. 5th European Wind Energy Association Conference (EWEC '94), 1994, PP. 1182-1187.

[14] J. Zhang, S. Ci, Sharif, and M. Alahmad, "An Enhanced circuit-based model for single-cell battery," in Proc.25th Applied Power Electronics Conference and Exhibition, Feb. 2010, pp. 672-675. 